

\title{
Analisis Metode Backpropagation Memprediksi Penerimaan Santri/Wati di Pondok Pesantren Modern Al-Kautsar
}

\author{
Parta Wijaya', Rahmat Widiya Sembiring ${ }^{2}$, Saifullah ${ }^{3}$ \\ ${ }^{1,3}$ STIKOM Tunas Bangsa, Pematangsiantar, Sumatera Utara, Indonesia \\ ${ }^{2}$ AMIK Tunas Bangsa, Pematangsiantar, Sumatera Utara, Indonesia \\ Jln. Sudirman Blok A No. 1-3 Pematangsiantar, Sumatera Utara \\ ${ }^{1}$ wparta28@gmail.com, ${ }^{3}$ saifullah@amiktunasbangsa.ac.id
}

\begin{abstract}
The development of technology today with the existence of artificial intelligence, conducted research to prove the Backpropagation method can predict students / wati in the modern boarding school Al-Kautsar. Artificial neural network is a method that is able to perform mathematical processes in predicting santri / wati. Bacpropagation algorithm is used to process data that is implemented with Matlab. Where data is collected through direct observation. Data is grouped by majors. The results obtained from the Matlab test performace and epoch values of each architecture are not the same as the results of the tests are displayed in the form of a graph comparing the target value with the research and testing process. The results of this study provide information on the modern Al-Kautsar boarding school on the number of registrants in 2020.
\end{abstract}

Keywords: Backpropagation, ANN, Islamic Boarding School, Matlab

Abstrak

Berkembangnya teknologi saat ini dengan adanya kecerdasan buatan maka dilakukan penelitian untuk membuktikan metode Backpropagation dapat memprediksi santri/wati pada pondok pesantren modern Al-Kautsar. Jaringan saraf tiruan merupakan metode yang mampu melakukan proses matematis dalam memprediksi santri/wati. Algoritma Bacpropagation digunakan untuk mengolah data yang di implementasikan dengan Matlab. Dimana data dikumpulkan melalui observasi langsung. Data di kelompokkan berdasarkan jurusan. Hasil yang di dapat dari pengujian Matlab nilai performance dan epoch setiap arsitektur tidak sama hasil pegujiannya di tampilkan dalam bentuk grafik perbandingan nilai target dengan proses penelitian dan pengujian. Dari hasil penelitian ini didapatkan bahwa jumlah pendaftar Santri/wati di Pondok pesantren Modern AlKautsar diprediksi mengalami kenaikan, dengan tingkat keakurasian 83,3 \% dengan epoch 2447 iterasi dalam waktu 00.16 detik adalah pengujian yang terbaik.

Kata kunci: Backpropagation, JST, Pesantren, Matlab

\section{PENDAHULUAN}

Pesantren adalah sebuah pendidikan tradisional yang para siswanya tinggal bersama dan belajar di bawah bimbingan guru yang lebih dikenal dengan sebutan kiai dan mempunyai asrama untuk tempat menginap santri. Jumlah pendaftar Santri/wati baru di pondok pesantren ini setiap tahunnya mengalami peningkatan dan penurunan, sehingga jumlah santri baru di pondok ini tidak stabil. Untuk menangani hal itu akan lebih baik jika penyelenggara mampu melakukan antisipasi untuk meminimalisir kelemahan yang ada dengan membuat model prediksi untuk melakukan prediksi jumlah Santri/wati baru yang akan masuk. Selain itu peramalan jumlah pendaftar Santri/wati baru sangat penting dilakukan untuk 
meningkatkan kulaitas dan strategi pemasaran yang baik sehingga jumlah pendaftar stabil dengan küota yang ada.

Disi in penulis menerrapkan sebuah metode Backpropagation yang mana metode tersebut dapat dijadikan solusi dalam memprediksi jumlah pendaftarsantri/wati baru yang mendaftar di pondok pesantren modern AlKautsar, karena metode ini merupakan bagian dari pembelajaran terawasi yang biasanya di gunakan untuk lapisan menentukan bobot-bobot yang tehubung dengan neuron-neouron yang ada pada lapisan yang tersembunyi. Yang mana metode Backpropagation tersebut akan di virtualsasikan ke dalam program matlab dan akan menghasilkan perhitungan yang valid.

Dari penjabaran diatas, yang menjadi latar belakang masalah darin penelitian ini adalah bagaimana jaringan saraf tiruan dengan Algoritma Backpropagation dalam membantu memprediksi jumlah calon pendaftar. Berdasarkan uraian diatas penelitian ini diharapkan dapat membantu peneliti lainnya untuk membandingkan, menganalisa serta mengenmbangkan algoritma yang berkaitan maupun diluar penelitian ini. Serta untuk mengetahui kekaurasian prediksi pendaftar baru pondok pesantren modern $\mathrm{Al}$ - Kautsar dan dapat membantu strategi pemasaran untuk meningkatkan pendaftar baru di pondok pesantren modern Al-Kautsar.

\section{METODOLOGI PENELITIAN}

\subsection{Pengumpulan Data}

Data yang dilakukan dalam penelitian ini diambil dari Pondok Pesantren Modern Al-Kautsar Panei Tongah Simalungun Data yang penulis gunakan dalam penelitian ini adalah data yang diperoleh dari Pondok Pesantren Modern AlKautsar dari tahun 2014 - 2020. Berikut ini merupakan data yang di peroleh dari Pondok Pesantren Modern Al-Kautsar.

Tabel 1. Tabel Jumlah Pendaftar

(Sumber : Pondok Pesantren Modern Al - Kautsar)

\begin{tabular}{|c|c|c|c|c|c|c|c|}
\hline \multirow{2}{*}{ No } & \multirow{2}{*}{ BULAN } & Tahun & Tahun & Thbu & Tah & Ta & Tahun \\
\hline & & 2014 & 2015 & 2016 & 2017 & 2018 & 2019 \\
\hline 1 & Madrasah Tsanawiyah Putri & 650 & 600 & 550 & 690 & 589 & 557 \\
\hline 2 & Madrasah Tsanawiyah Putra & 700 & 500 & 460 & 654 & 568 & 589 \\
\hline 3 & Madrasah Aliyah & 776 & 632 & 655 & 564 & 630 & 576 \\
\hline 4 & IPA PUTRA & 576 & 600 & 643 & 765 & 680 & 586 \\
\hline 5 & IPA PUTRI & 660 & 523 & 700 & 638 & 675 & 575 \\
\hline 6 & IPS PUTRA & 450 & 455 & 508 & 566 & 458 & 700 \\
\hline 7 & IPS PUTRI & 500 & 500 & 700 & 559 & 589 & 755 \\
\hline 8 & NAHWU PUTRA & 660 & 687 & 605 & 685 & 601 & 655 \\
\hline 9 & NAHWU PUTRI & 760 & 544 & 586 & 576 & 659 & 580 \\
\hline 10 & ILMU SHOROF PUTRA & 800 & 540 & 674 & 586 & 559 & 564 \\
\hline 11 & ILMU SHOROF PUTRI & 600 & 607 & 553 & 655 & 489 & 660 \\
\hline 12 & KITAB KUNING PUTRA & 550 & 589 & 600 & 640 & 500 & 580 \\
\hline 13 & KITAB KUNING PUTRI & 500 & 654 & 580 & 590 & 480 & 600 \\
\hline
\end{tabular}




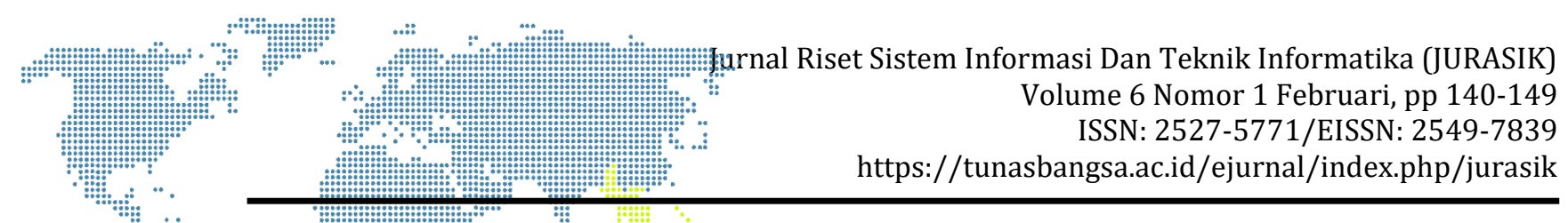

\subsection{Metode fenelitian}

1. Jaringan Syaraf Tiruan

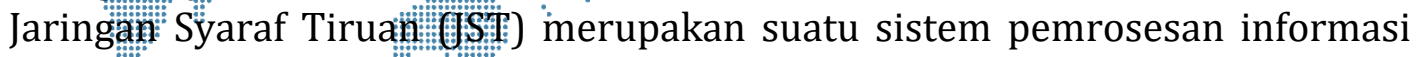
yang mempunyai karakteristík menyerupai jaringan syaraf biologis (JSB) Jaringan Syaraf Tiruan tercipta sebagai suatu generalisasi model matematis dari pemahaman manusia (human cognition) [1]. JST berupa susuan sel - sel saraf tiruan (neuron) dibangun berdsarkan prinsip - prinsip organisasi otak manusia. Salah satu metode yang digunakan dalam JST adalah Backpropagation[2][3].

2. Backpropagation

Keunggulan utama dari sistem algoritma backpropagation adalah kemampuan "belajar" dari contoh yang diberikan. Backpropagation merupakan algoritma pembelajaran yang terawasi dan biasanya digunakan oleh perceptron dengan banyak layar lapisan untuk mengubah bobot-bobot yang ada pada lapisan tersembunyinya. "Algoritma backpropagation adalah algoritma iteratif yang mudah dan sederhana yang biasanya berkinerja baik, bahkan dengan data yang kompleks" [4][5][6].

\section{HASIL DAN PEMBAHASAN}

\subsection{Perhitungan Menggunakan Backpropagation}

Dalam melakukan pelatihan dan pengujian hasil dari pengolahan data untuk memprediksi jumlah pendaftar baru sanri/wati baru di pondok pesantrean modern Al-Kautsar, maka pengolahan data tersebut juga akan diujikan ke dalam sistem komputerisasi. Backpropagation terdiri dari $\mathrm{n}$ buah masukan(ditambah sebuah bias), sebuah layar tersembunyi yang terdiri dari p unit (ditambah sebuah bias), serta $\mathrm{m}$ buah unit keluaran. Voj dan Wok masing-masing adalah bias untuk unit tersembunyi ke-j dan untuk output ke-k. Bias Voj dan Wok berperilaku seperti bobot dimana output bias ini selalu sama dengan 1[1] Dalam melakukan pengujian data, penulis menggunakan software Matlab R2011.

Langkah pertama yang harus dilakukan dalam menerapkan algoritma backpropagation untuk memprediksi jumlah pendaftar baru adalah membagi data yang akan diuji menjadi dua (2) bagian, dimana bagian pertama adalah untuk data pelatihan (Traning) dan bagian kedua adalah untuk data pengujian (Testing). Pada penelitian ini terdapat lima model arsitektur yang digunakan untuk pelatihan dan pengujian data yaitu model 3-2-1, 3-4-1, 3-5-1, 3-6-1, 3-9-1.

Pelatihan dan pengujian data dengan algoritma backpropagation pada tahap pertama ini menggunakan arsitektur jaringan 3-2-1. Yang di maksud disini layer masukan menggunakan 3 Neuron, layer tersembunyi 2 serta 1 neuron keluaran. Source code pelatihan backpropagation yang digunakan dengan aplikasi Matlab sebagai berikut:

a) >>net=newff( $\operatorname{minmax}(P),[2,1],\{$ 'tansig','logsig'\},'traingd');

Perintah ini digunakan untuk membentuk jaringan pada backpropagation yang mempunyai 2 neuron hidden dan 1 neuron target.

b) >> net.IW $\{1,1\}$;

Net.IW $\{1,1\}$ bobot pertama yang digunakan untuk bobot hidden. 


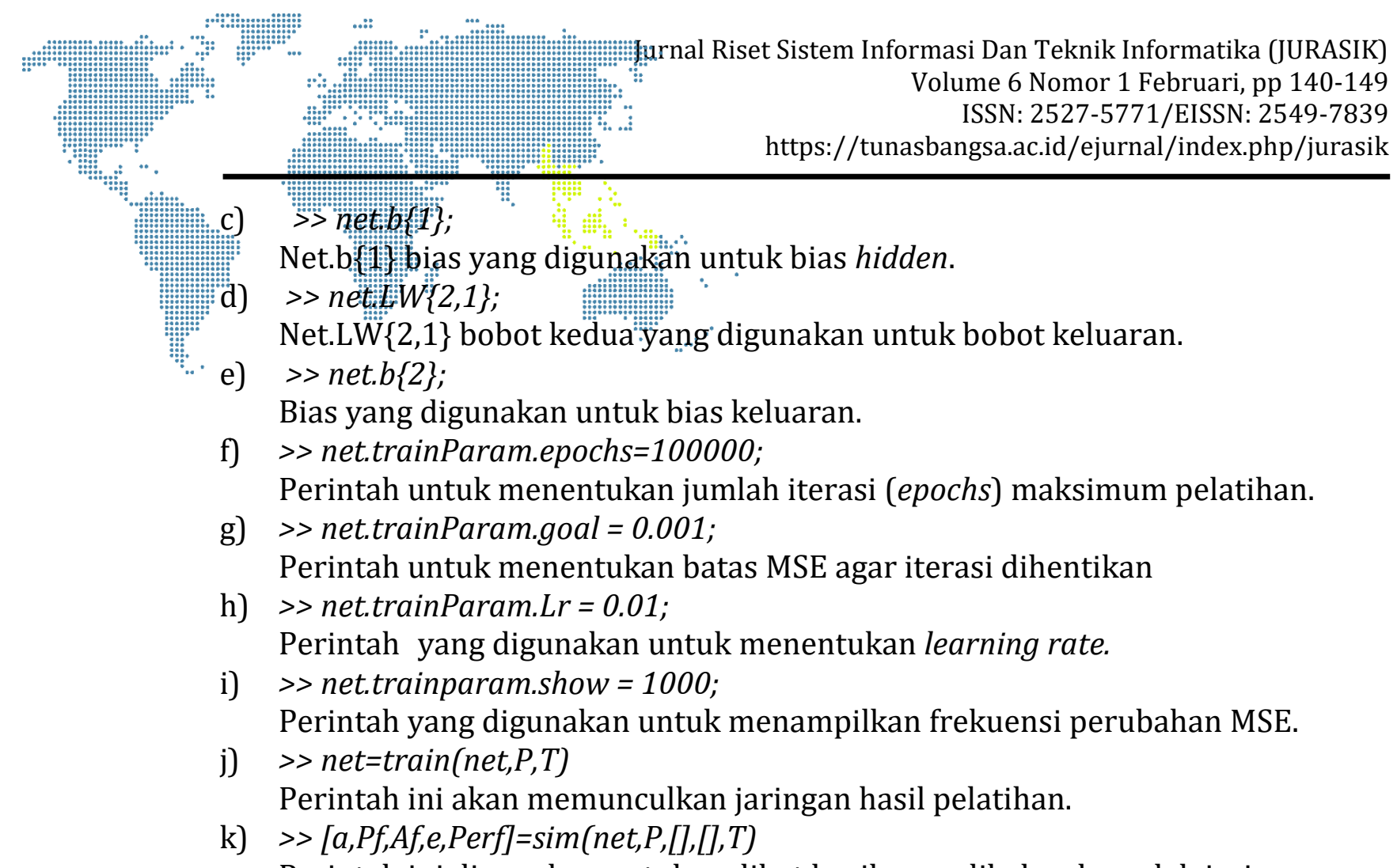

Perintah ini digunakan untuk melihat hasil yang dikeluarkan oleh jaringan.

Pelatihan dan pengujian Jaringan Syaraf Tiruan dengan arsitektur 3-2-1 dapat dilihat pada Gambar 1 dan 2 berikut :

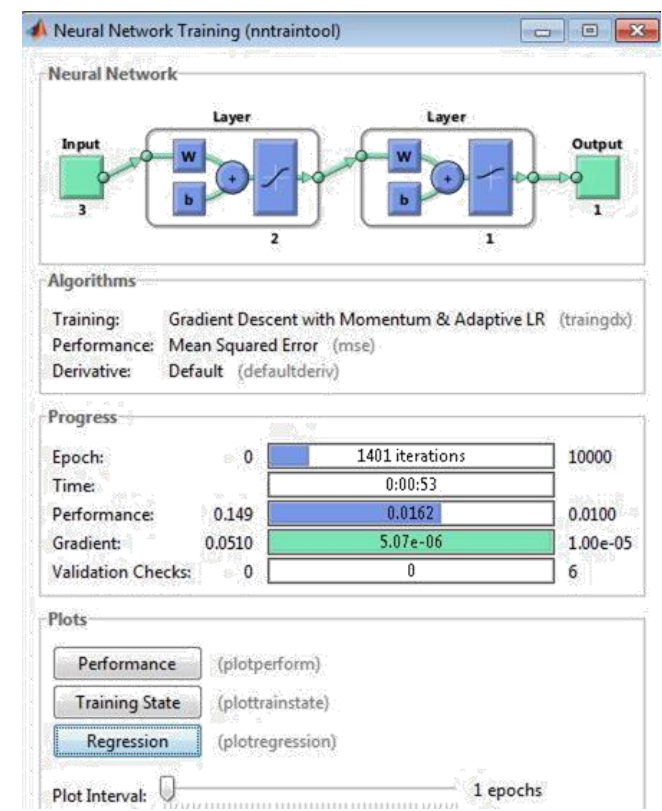

Gambar 1. Pelatihan Arsitektur Backpropagation Menggunakan 3-2-1

Berdasarkan Gambar 1 dapat dilihat bahwa model jaringan dengan arsitektur 3-2-1 menghasilkan epoch sebesar 1401 dalam waktu 00:53 detik.

Dapat dipahami untuk penjelasan simbol-simbolnya:

a) Simbol $b_{i}$ Menunjukkan nilai bias,.Nilai bias ini mirip dengan nilai bobot hanya dengan nilai bobot hanya saja tidak dikalikan dengan input. 
urnal Riset Sistem Informasi Dan Teknik Informatika (JURASIK) Volume 6 Nomor 1 Februari, pp 140-149 ISSN: 2527-5771/EISSN: 2549-7839 https://tunasbangsa.ac.id/ejurnal/index.php/jurasik

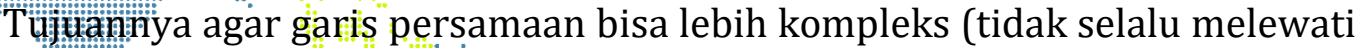
titikeremigin).

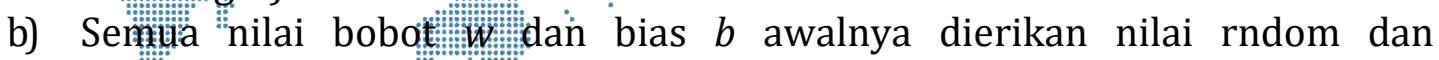
diperbarui nilainya dengan proses backrop untuk meningkatkan kualitas model.

c) N menunjukkan banyak neuron di layer sebelah kiri (layer input).

d) Simbol (sigma) adalah simbol dari fungsi aktivasi. Artinya setelah proses perkalian input dan bobot $w$ lalu dilakukan penjumlahan semua, langkah selanjutnya adalah mengenai hasil perhitungan tersebut dengan fungsi aktivasi. Ada banyak fungsi aktivasi



Gambar 2. Best Training Performance Menggunakan Arsitektur 3-2-1

e) Pada Gambar 2 menunjukkan error goal (MSE) pada pelatihan ini sebesar 0,0018935 dicapai pada epoch yang ke 10000 .

f) Berdasarkan uraian tersebut berikut akurasi data pelatihan arsitektur 3-21, dapat dilihat pada Tabel 2. dibawah:

Tabel 2. Akurasi Data Pelatihan (Traning) Arsitektur 3-2-1

\begin{tabular}{|c|c|c|c|c|c|}
\hline No & Pola & Target & Output & Error & SSE \\
\hline 1 & Pola 1 & 0,44581 & 0,348638 & 0,09717 & 0,00944 \\
\hline 2 & Pola 2 & 0,39161 & 0,336187 & 0,05543 & 0,00307 \\
\hline 3 & Pola 3 & 0,55161 & 0,45103 & 0,10058 & 0,01012 \\
\hline 4 & Pola 4 & 0,68065 & 0,447498 & 0,23315 & 0,05436 \\
\hline 5 & Pola 5 & 0,66774 & 0,467694 & 0,20005 & 0,04002 \\
\hline 6 & Pola 6 & 0,10774 & 0,449119 & $-0,34138$ & 0,11654 \\
\hline 7 & Pola 7 & 0,44581 & 0,468188 & $-0,02238$ & 0,00050 \\
\hline 8 & Pola 8 & 0,47677 & 0,314061 & 0,16271 & 0,02648 \\
\hline 9 & Pola 9 & 0,62645 & 0,451464 & 0,17499 & 0,03062 \\
\hline 10 & Pola 10 & 0,36839 & 0,466493 & $-0,09811$ & 0,00962 \\
\hline 11 & Pola 11 & 0,18774 & 0,351085 & $-0,16334$ & 0,02668 \\
\hline 12 & Pola 12 & 0,21613 & 0,435732 & $-0,21960$ & 0,04823 \\
\hline 13 & Pola 13 0,16452 & 0,342279 & $-0,17776$ & 0,03160 \\
\hline \multicolumn{5}{|c|}{ Jumlah SEE } & 0,37567 \\
\hline
\end{tabular}


Pada fabel 2 dapat di lihat akurasi dari data pelatihan arsitektur 3-2-1 yang telah di tentukan dengân menggunakan persamaan yang telah di tetapkan. Terdapat pola 1 s/d 13 adälah polả yang dipakai dalam data pelatihan. Nilai Target diperoleh dari tabel data pelatihan yang sudah dinornalisasi. Nilai Output diperoleh dari rumus $[a, P f, A f, e, P e r f]=\operatorname{sim}($ net $, P,[],[], T)$ yang dimasukkan pada aplikasi Matlab dari input dan data target data pelatihan. Nilai Error diperoleh dari : Target-Output. SSE diperoleh dari : Error ${ }^{\wedge} 2$ ( ${ }^{\wedge}$ : Pangkat). Jumlah SSE adalah total dari keseluruhan SSE. MSE diperoleh dari : jumlah SSE / 12 (jumlah data). Berikut akurasi data pengujian arsitektur 3-2-1, dapat dilihat pada Tabel 3. dibawah :

Tabel 3. Akurasi Data Pengujian (Testing) Arsitektur 3-2-1

\begin{tabular}{|c|c|c|c|c|c|c|}
\hline No & Pola & Target & Output & Error & SSE & Hasil \\
\hline 1 & Pola 1 & 0,36323 & 0,466851 & $-0,10363$ & 0,01074 & 1 \\
\hline 2 & Pola 2 & 0,44581 & 0,467937 & $-0,02213$ & 0,00049 & 1 \\
\hline 3 & Pola 3 & 0,41226 & 0,29118 & 0,12108 & 0,01466 & 0 \\
\hline 4 & Pola 4 & 0,43806 & 0,466349 & $-0,02828$ & 0,00080 & 1 \\
\hline 5 & Pola 5 & 0,40968 & 0,365691 & 0,04399 & 0,00193 & 1 \\
\hline 6 & Pola 6 & 0,73226 & 0,458206 & 0,27405 & 0,07510 & 0 \\
\hline 7 & Pola 7 & 0,87419 & 0,193931 & 0,68026 & 0,46276 & 0 \\
\hline 8 & Pola 8 & 0,61613 & 0,462714 & 0,15341 & 0,02354 & 0 \\
\hline 9 & Pola 9 & 0,42258 & 0,414231 & 0,00835 & 0,00007 & 1 \\
\hline 10 & Pola 10 & 0,38129 & 0,326612 & 0,05468 & 0,00299 & 0 \\
\hline 11 & Pola 11 & 0,62903 & 0,465282 & 0,16375 & 0,02681 & 0 \\
\hline 12 & Pola 12 0,42258 & 0,45688 & $-0,03430$ & 0,00118 & 1 \\
\hline 13 & Pola 13 0,47419 & 0,444791 & 0,02940 & 0,00086 & 1 \\
\hline \multicolumn{7}{|c|}{ Jumlah SEE } \\
\cline { 1 - 3 }
\end{tabular}

\subsection{Pembahasan}

Dari model arsitektur 3-2-1 dapat diketahui bahwa tingkat akurasi Pengujian sebesar 50,7\%. Pola $1 \mathrm{~s} / \mathrm{d} 12$ adalah pola yang dipakai dalam data pengujian. Nilai Target diperoleh dari tabel data engujian yang sudah dinormalisasi. Nilai Output diperoleh dari rumus $[a, P f, A f, e, P e r f]=\operatorname{sim}($ net $, P,[],[], T)$ yang dimasukkan pada aplikasi Matlab dari input dan target data pengujian. Nilai Error diperoleh dari : Target-Output. SSE diperoleh dari : Error ${ }^{\wedge} 2$. Jumlah SSE adalah total dari keseluruhan SSE. MSE diperoleh dari : Jumlah SSE / 12 (jumlah data). Hasil bernilai 1 (Benar) apabila nilai SSE $<=0,05$ adalah target error dari pengujian backpropagation. Dan akurasi (\%) diperoleh dari : Jumlah Benar / $12 * 100$.

Dan begitu seterusnya untuk model 3-4-1, 3-5-1, 3-6-1, 3-9-1. Selanjutnya semua data yang sudah diolah akan disimpulkan kembali agar mendapat model arsitektur terbaik. Pada penelitian ini terdapat lima model arsitektur yaitu 3-2-1, 3-4-1, 3-5-1, 3-6-1, 3-9-1, dari ke 5 model tersebut dapat diperoleh satu model arsitektur terbaik.

Pada tahapan ini akan dilakukan pengamatan terhadap laju pembelajaran kinerja jaringan dengan parameter tingkat akurasi, waktu pembelajaran, MSE selama proses pelatihan dan lamanya waktu iterasi (Epoch). Dengan memakai arsitektur jaringan terbaik pada pelatihan, maka akan diamati laju pembelajaran 
terhadap kinerja jaringan Berdasarkan Tabel diatas dapat disimpulkan bahwa dalam melakkan proses pendätar santri baru dengan menerapkan algoritma backpropagation yang mejigganakan lima (5) model arsitektur. Dari kelima model arsitektur tersebut diperoleh satu (1) model terbaik yaitu 3-9-1 dengan tingkat keakurasian 83,3 \% dengan epoch 2447 iterasi dalam waktu 00.16 detik. Pada penelitian ini, model arsitektur terbaik akan diterapkan untuk proses prediksi terhadap jumlah pendaftar baru di Pondok Pesantren Modern Al-Kautsar. Pada penelitian ini, tahap terakhir yang akan dilakukan adalah proses prediksi jumlah pendaftar santri/wati baru ditahun yang akan datang. Setelah didapatkan model arsitektur terbaik dari algoritma Backpropagation, selanjutnya akan dilakukan proses prediksi, Tahapan ini dilakukan dengan melakukan pengujian dengan menerapkan model arsitektur 3-9-1 menggunakan software Matlab R2011b, model ini digunakan untuk mengetahui seberapa akuratnya model arsitektur 3-9-1 dalam memperoleh suatu hasil yang diinginkan.

Dalam melakukan proses prediksi terhadap jumlah pendaftar baru santri/wati ditahun yang akan datang maka akan dilakukan pengolahan data dengan melakukan pengujian data secara komputerisasi. Proses yang dilakukan sama dengan melakukan pelatihan terhadap data awal, namun dalam proses prediksi pengujian data yang dilakukan pada software Matlab R2011b menggunakan model arsitektur 3-9-1 untuk mengetahui seberapa besar keakuratan suatu model arsitektur terbaik yang diperoleh.

Dalam melakukan pengujian data untuk memperoleh hasil prediksi yang diinginkan menggunakan model arsitektur 3-9-1 terbaik yang diperoleh melalui langkah yang sudah dilakukan penulis menggunakan software Matlab R2011b. Adapun hasil prediksi terhadap jumlah penduduk untuk tahun 2020 dapat dilihat pada Tabel 4. berikut.

Tabel 4. Prediksi Pendaftar baru Tahun 2021

\begin{tabular}{|c|c|c|c|c|}
\hline \multicolumn{5}{|c|}{ Prediksi 2021 } \\
\hline No & $\begin{array}{c}\text { Data } \\
\text { Real }\end{array}$ & Target & $\begin{array}{c}\text { Target } \\
\text { Prediksi }\end{array}$ & Prediksi \\
\hline 1 & 557 & 0,418376064 & 0,406996256 & 633 \\
\hline 2 & 589 & 0,358500431 & 0,491310184 & 654 \\
\hline 3 & 576 & 0,492715298 & 0,205099626 & 583 \\
\hline 4 & 586 & 0,673503235 & 0,756346283 & 719 \\
\hline 5 & 575 & 0,664787031 & 0,458338267 & 646 \\
\hline 6 & 700 & 0,195188415 & 0,41764975 & 636 \\
\hline 7 & 755 & 0,489351245 & 0,386858827 & 628 \\
\hline 8 & 655 & 0,321989802 & 0,455063146 & 645 \\
\hline 9 & 580 & 0,421620213 & 0,369758186 & 624 \\
\hline 10 & 564 & 0,408050899 & 0,457298819 & 645 \\
\hline 11 & 660 & 0,258820894 & 0,468501998 & 648 \\
\hline 12 & 580 & 0,322425668 & 0,495347589 & 655 \\
\hline 13 & 600 & 0,341222892 & 0,410016522 & 634 \\
\hline
\end{tabular}

Pada Tabel 4. dapat diihat hasil dari prediksi tahun 2020 adapun penjelasan dari tabel tersebut yaitu : 


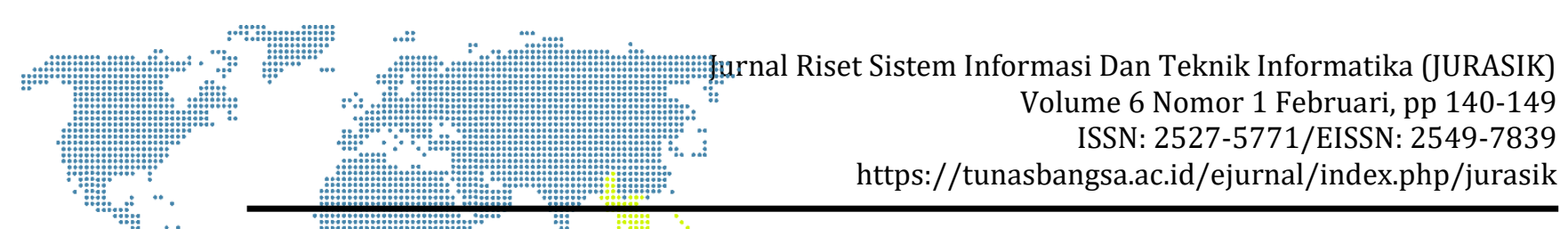

1) ${ }_{1}$ Bata Real diperoleh dari data asli tahun terakhir

2) Bata Target diperolè dari data testing yang sudah di normalisasi

3) "ibata Target Pifediuksi "diperoleh dari hasil pengujian menggunakan Software Matlab $2011 \mathrm{~b}$, adapun paramater pencarian data target prediksi sebagai berikut :

a. >>net=newff(minmax (PP),[9,1].\{'tansig','logsig'\},'traingd');

b. >> net $=I W\{1,1\}$;

c. $>>$ net. $b\{1\}$;

d. $>>$ net.LW $\{2,1\}$;

e. $>>$ net.b $\{2\}$;

f. $>>$ net.trainParam.epochs $=100000$;

g. $>>$ net.trainParam.goal $=0.001$;

h. $>>$ net.trainParam.Lr=0.01;

i. $>$ net.trainParam.show $=1000$;

j. $\quad>$ net=train(net, $P P, T T)$

Setelah semua parameter selesai di input akan tampil proses pengujian prediksi pertama dengan model arsitektur 3-9-1

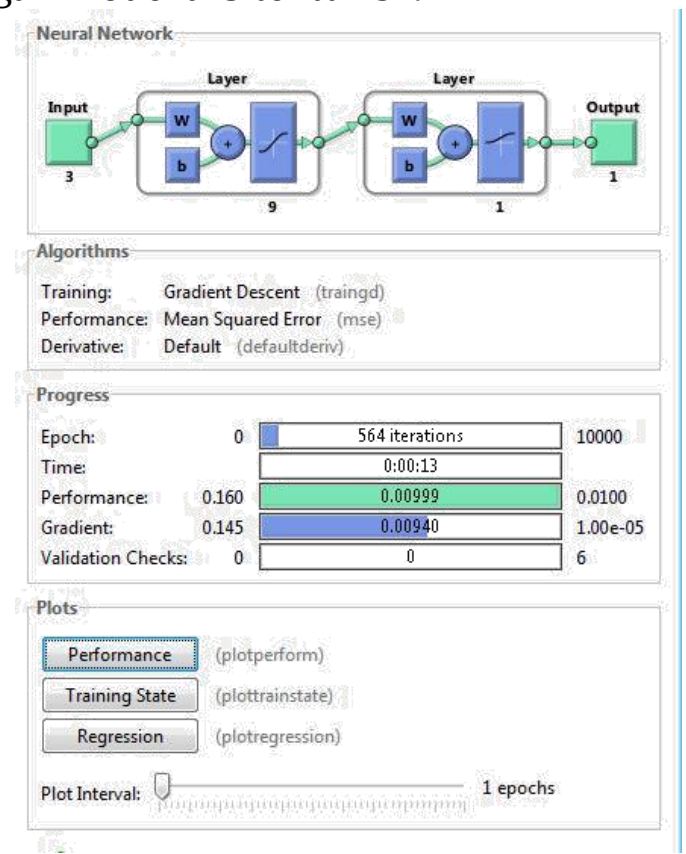

Gambar 3. Pengujian Prediksi 2 Menggunakan Arsitektur 3-9-1

Dari Gambar 3 menunjukan bahwa hasil pengujian arsitektur 3-9-1 menghasilkan epoch sebesar 564 dengan lama waktu 00:13 detik. Setelah proses pengujian selesai, selanjutnya untuk mendapatkan hasil target prediksi digunakan rumus :

$[a, P f, A f, e, P e r f]=\operatorname{sim}($ net $, P P,[],[], T T)$

Untuk mencari data prediksi digunakan rumus sebagai berikut :

Prediksi $=\left|\frac{(X n-0,1)^{\prime}(b-a)}{0,8+a}\right|$ 
Untuk mempermudah dalam memahami data yang diperoleh, maka penulis menyusu il iasil prediksi dengan data awal menjadi satu kesatuan. Pada penelitian ini, penulis memlakukan prediliss dảlam rentang waktu 2 tahun kedepan terhitung dari tahun 2019-2021. Berdasarkan hasil prediksi yang diperoleh, jumlah blanko mengalami peningkatan disetiap tahunnya . Namun dalam hal ini, hasil prediksi yang diperoleh menggunakan model arsitektur terbaik yang diperoleh yaitu model 3-9-1 dengan tingkat akurasi 91,7\% dan epoch sebesar 564 iterasi dalam waktu 00:13 detik merupakan suatu hal yang masih merupakan prediksi yang dapat digunakan sebagai acuan atau tidak, dalam menerapkan suatu algoritma backpropagation untuk memprediksi jumlah blanko. Dengan hasil prediksi yang sudah diperoleh dapat digunakan sebagai antisipasi untuk bahan motivasi dalam persediaan stok blanko pada kantor Badan Pertanahan Nasional Kota Pematangsiantar. Berikut hasil akhir kesimpulan prediksi yang sudah diperoleh dengan menggunakan algoritma backpropagation dalam memprediksi jumlah pendaftar baru dalam rentang waktu 2 tahun ke depan terhitung dari tahun 20192021 dapat dilihat di Tabel 5 .

Tabel 5. Prediksi Jumlah Pendaftar Baru Santri 2 Tahun Ke Depan

\begin{tabular}{|c|l|c|c|c|c|c|c|c|}
\hline No & \multicolumn{1}{|c|}{ BULAN } & Tahun & Tahun & Tahun & Tahun & Tahun & Tahun & Tahun \\
\cline { 3 - 8 } & & $\mathbf{2 0 1 5}$ & $\mathbf{2 0 1 6}$ & $\mathbf{2 0 1 7}$ & $\mathbf{2 0 1 8}$ & $\mathbf{2 0 1 9}$ & $\mathbf{2 0 2 0}$ & $\mathbf{2 0 2 1}$ \\
\hline 1 & $\begin{array}{l}\text { Madrasah } \\
\text { Tsanawiyah Putri }\end{array}$ & 600 & 550 & 690 & 589 & 557 & 543 & 633 \\
\hline 2 & $\begin{array}{l}\text { Madrasah } \\
\text { Tsanawiyah Putra }\end{array}$ & 500 & 460 & 654 & 568 & 589 & 567 & 654 \\
\hline 3 & Madrasah Aliyah & 632 & 655 & 564 & 630 & 576 & 487 & 583 \\
\hline 4 & Ipa Putra & 600 & 643 & 765 & 680 & 586 & 640 & 719 \\
\hline 5 & Ipa Putri & 523 & 700 & 638 & 675 & 575 & 557 & 646 \\
\hline 6 & Ips Putra & 455 & 508 & 566 & 458 & 700 & 546 & 636 \\
\hline 7 & Ips Putri & 500 & 700 & 559 & 589 & 755 & 538 & 628 \\
\hline 8 & Nahwu Putra & 687 & 605 & 685 & 601 & 655 & 557 & 645 \\
\hline 9 & Nahwu Putri & 544 & 586 & 576 & 659 & 580 & 533 & 624 \\
\hline 10 & Ilmu Shorof Putra & 540 & 674 & 586 & 559 & 564 & 557 & 645 \\
\hline 11 & Ilmu Shorof Putri & 607 & 553 & 655 & 489 & 660 & 560 & 648 \\
\hline 12 & Kitab Kuning Putra & 589 & 600 & 640 & 500 & 580 & 568 & 655 \\
\hline 13 & Kitab Kuning Putri & 654 & 580 & 590 & 480 & 600 & 544 & 634 \\
\hline
\end{tabular}

\section{SIMPULAN}

Berdasarkan pembahasan sebelumnya dapat disimpulkan bahwa:

a) Penggunaan metode Backpropogation dapat di gunakan didalam prediksi jumlah pendaftar baru santri/wati yang mana memiliki data valid sehingga mendapatkan hasil yang seknifikat.

b) Hasil yang di dapat dari analisa metode Backpropogation dan virtualisasi mengunakan aplikasi matlab dapat di hasilkan dengan data yang valid. Dan di simpulkan bahwa metode Backpropogation dapat di jadikan sebagai metode prediksi yang sangat memudahkan untuk mencari prediksi apapun.

\section{DAFTAR PUSTAKA}

[1] A. Sudarsono, "Jaringan Syaraf Tiruan Untuk Memprediksi Laju Pertumbuhan Penduduk Menggunakan Metode," Media Infotama, Vol. 12, No. 1, Pp. 61-69, 2016. 


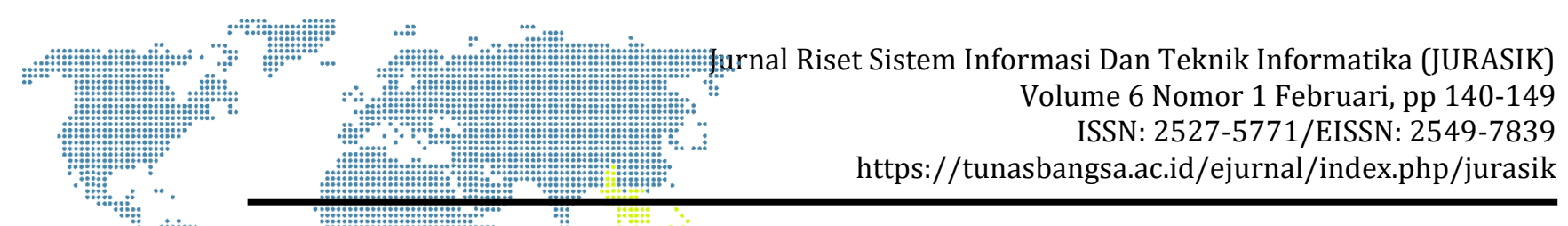

[2] C. Oktaviani And AfdaI, "Prediksi Curah Hujan Bulanan Menggunakan Jaringan Syaume Tiruan Dengan Beberiapa Fungsi Pelatihan Backpropagation," J. Fis. Unand, Vol.2. No: 4, Pp. 228-Z3itz:2013.

[3] A. F.:Setiawan And A. K. Agung, "Klasifikasi Pola Sidik Jari Menggunakan Jaringan Syaraf Tiruan Backpropagatiön Untuk Analisa Karakteristik Seseorang," Antivirus J. Ilm. Tek. Inform., Vol. 10, No. 2, Pp. 50-55, 2016, Doi: 10.35457/Antivirus.V10i2.162.

[4] I. S. Purba And A. Wanto, "Prediksi Jumlah Nilai Impor Sumatera Utara Menurut Negara Asal Menggunakan Algoritma Backpropagation," Techno.Com, Vol. 17, No. 3, Pp. 302-311, 2018, Doi: 10.33633/Tc.V17i3.1769.

[5] B. Febriadi, Z. Zamzami, Y. Yunefri, And A. Wanto, "Bipolar Function In Backpropagation Algorithm In Predicting Indonesia's Coal Exports By Major Destination Countries," In Iop Conference Series, 2018, Pp. 1-8.

[6] Y. A. Lesnussa, S. Latuconsina, And E. R. Persulessy, "Aplikasi Jaringan Saraf Tiruan Backpropagation Untuk Memprediksi Prestasi Siswa Sma ( Studi Kasus : Prediksi Prestasi Siswa Sman 4 Ambon )," Vol. 11, No. 2, Pp. 149-160, 2015. 